\title{
Thickening of Jakobshavns Isbræ, West Greenland, measured by airborne laser altimetry
}

\author{
R. Thomas, \\ Code IS, NASA HQ Washington DC 20546, U.S.A. \\ W. KRABILL, \\ NASA/Wallops Flight Facility, Code 972, Wallops Island, VA 23337, U.S.A. \\ E. FREDERICK, \\ EG \& G, NASA/Wallops Flight Facility, Code 972, Wallops Island, VA 23337, U.S.A. \\ K. JEZEK \\ Byrd Polar Research Center, The Ohio State University, Columbus, OH 43210, U.S.A.
}

\begin{abstract}
NASA flights over southern Greenland in 1991, 1992 and 1993, using a scanning laser altimeter with Global Positioning System (GPS) navigation, have demonstrated a capability to measure ice-surface elevations to an accuracy of 10$15 \mathrm{~cm}$. Flights over Jakobshavns Isbræ revealed winter thickening by several meters between September 1991 and April 1992. By July 1993, surface elevations showed a small additional increase, possibly associated with the cold 1992 summer. Data collected over the ice sheet east of Jakobshavns Isbra show negligible change over the same period; but further south, at latitude $65^{\circ} \mathrm{N}$, the western part of the ice sheet appears to have thickened by up to $2 \mathrm{~m}$ between 1980 and 1993. It is clear that such measurements must be continued over many years, both to quantify the effects of interannual variability and to measure long-term trends. To this end, we plan to complete a first survey of all major drainage basins on the ice sheet in May-June 1994, and then to resurvey all flight lines at $5 \mathrm{a}$ intervals, with more frequent flights over selected routes.
\end{abstract}

\section{INTRODUCTION}

Mass balance is generally computed by comparing estimates of total snow accumulation with estimates of total loss by both melting and ice discharge - the comparison of two very large numbers, each of which has significant errors. A more direct indication of ice-sheet mass balance can be obtained by comparing precise, repeat measurements of surface-elevation profiles across the ice. Time series of elevation measurements by satellite radar altimeters have been used in this way to estimate ice-sheet thickening rates (Zwally and others, 1989). Unfortunately, these data are of insufficient accuracy to detect thickening/thinning rates over surfaces with slopes of more than about $1^{\circ}$. Moreover, errors are introduced by surface slopes and undulations within the beamlimited footprint and by radar penetration into the surface snow. Consequently, satellite radar-altimetry data are of little use for change detection over the margins of ice sheets and over individual glaciers, precisely the regions where we would expect elevation changes to be greatest.

Many of these problems can be overcome by using an airborne radar or laser altimeter with a footprint of a few tens of centimeters to a few meters. Consequently, in September 1991, April 1992 and June-July 1993, NASA conducted airborne altimeter missions over Greenland in an attempt to determine whether icesurface elevations can be measured from an aircraft to the accuracy needed to detect ice thinning or thickening over periods of a few years. The results are promising, indicating that we can measure ice-surface elevations to an accuracy of better than $15 \mathrm{~cm}$ over flight lines of several hundred kilometers (Krabill and others, in press). Here, we present results from repeated flight lines over Jakobshavns Isbræ showing significant thickening of the ice.

\section{MEASUREMENT SYSTEM}

The instrument complement included: several Global Positioning System (GPS) receivers linked to antennas at various locations on the aircraft fuselage, tail and wings; a scanning laser altimeter; a nadir-looking laser altimeter; a radar altimeter; and, in 1993, a radio-frequency ice- 
penetrating radar. In 1991 we also carried a multi-beam radar altimeter. With the overall goal of establishing an airborne capability to measure ice thickening/thinning rates, we aimed to measure ice-surface elevation to better than $20 \mathrm{~cm}$. This required making range measurements to the ice surface with an accuracy of a few centimeters, and determining aircraft location to better than $10 \mathrm{~cm}$. Moreover, later surveys must be made over precisely the same areas of the ice sheet. This latter requirement cannot be met by nadir-looking altimeters because aircraft tracks over long distances are bound to meander at least a few tens of meters off the desired track. Consequently, our prime altimeter was a conically scanning laser, the Airborne Oceanographic Lidar (AOL) Krabill and Swift, 1985). This has the advantage of providing a swath of measurements beneath the aircraft but the disadvantage of magnifying the effect of errors in aircraft attitude, which consequently must be known to within a few hundredths of a degree. In this paper, we use only results from the AOL.

The laser beam of the AOL is deflected by a nutating mirror to scan off-nadir and produce an elliptical spiral of data points as the aircraft moves forward. This provides elevation estimates within a swath of diameter approximately one-third to one-half the aircraft ground clearance (generally about $400 \mathrm{~m}$ ), depending on the off-nadir angle. The laser spot on the surface was approximately $1 \mathrm{~m}$ in diameter. With a laser pulse rate of $800 \mathrm{~s}^{-1}$ and with 5 conical scans $\mathrm{s}^{-1}$, the maximum along-track separation between laser footprints was $20 \mathrm{~m}$, and the cross-track separation less than $4 \mathrm{~m}$. Ranges were calculated from the time interval between laser-pulse transmission and receipt of the reflected pulse. For each flight, measured ranges are calibrated over a measured base line to a fixed target. Errors are estimated to be at the $5 \mathrm{~cm}$ level.

Aircraft attitude pitch, roll and heading were measured by an Inertial Navigation Unit (INU). Data, collected while flying at different roll and pitch angles over the horizontal ocean surface in a fjord, are analyzed to provide estimates of mounting biases between the AOL axes and those of the INU. In addition, data from three widely separated GPS antennas on the aircraft provided independent estimates of aircraft attitude in order to monitor INU drift during flight.

Aircraft location was determined using differential GPS techniques, requiring simultaneous acquisition of GPS data aboard the aircraft and at a fixed location (Krabill and Martin, 1987). High accuracy requires extensive post-processing, and is not achieved until after the flight. We also used real-time GPS data to provide the pilot with a visual display of the flight line and the current offset from desired track (Wright, 1992). Data from the 1991 and 1993 seasons indicate that most of the flight lines were within $50 \mathrm{~m}$ of the prescribed track.

Flights were made out of Kangerlussuaq, southwest Greenland. Most flights included passes over a stretch of the runway that had been surveyed in great detail using surface-based GPS. Data from these overpasses agree to within $12 \mathrm{~cm}$ (Krabill and others, in press). Flights were also made over locations on the ice sheet where groundbased GPS observations provide an independent estimate of surface elevation. These also agreed at the $10 \mathrm{~cm}$ level.

910912EW M 910912NS ALIN2.5

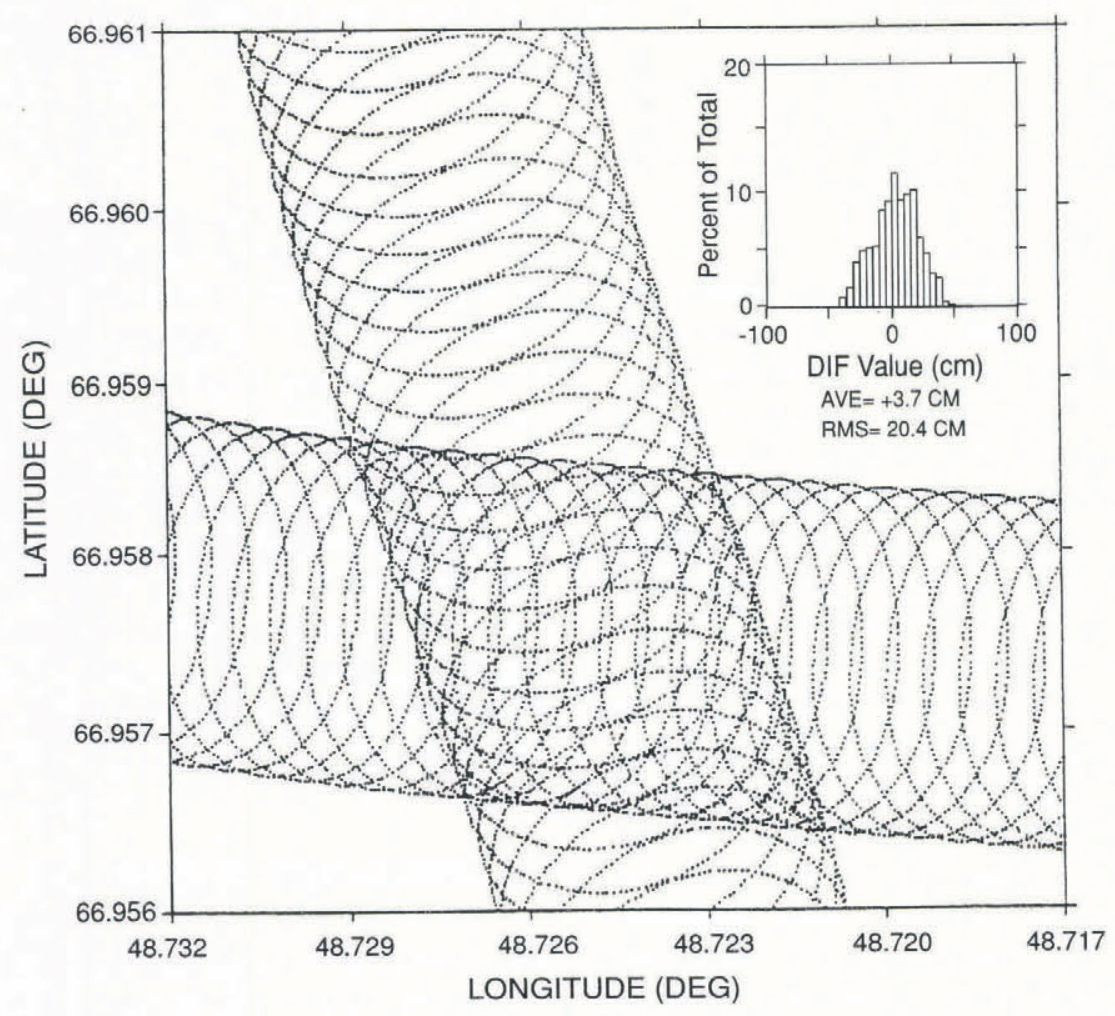

Fig. 1. Airborne laser-altimeter measurements at a location where an east-west flight line (on 12 September 1991) crosses a north-south line on the same day. The insel shows a histogram of elevation differences. 
A further check on data consistency is provided by comparing results from flights over identical routes and from locations where flight lines crossed (Fig. 1). The 1991 measurements showed agreement to better than $25 \mathrm{~cm}$, with half agreeing to better than $10 \mathrm{~cm}$. In 1993, most repeat-track measurements agreed to within $10 \mathrm{~cm}$. This improvement was associated primarily with an increase in the complement of GPS satellites, which yielded better aircraft trajectories, but also with improvements in our calibration techniques and measurement procedures resulting from lessons learned during 1991. On some occasions these repeat flights were separated by several days, so part of the observed difference may have been real.

In 1993, many flights passed over the same $70 \mathrm{~km}$ track as they left and returned to Kangerlussuaq. The western end of this segment suffered significant changes due to motion and melting even during one day. But the easternmost $40 \mathrm{~km}$ provided a stable enough surface to make meaningful comparisons, and data from most "out", and "back" flights showed agreement to better than $5 \mathrm{~cm}$. The results from 1991 and 1992 presented here are accurate to approximately $20 \mathrm{~cm}$, and those from 1993 to about $10 \mathrm{~cm}$. The elevation changes suggested by comparing the data are far larger than this.

\section{RESULTS}

In September 1991, April 1992 and July 1993, we overflew a route down Jakobshavns Isbræ (Fig. 2). In its lower reaches, Jakobshavns Isbræ moves approximately $8 \mathrm{~km}$ every year, making it the world's fastest glacier. It drains a very large area of Greenland into a fjord that is only $5 \mathrm{~km}$ wide. Within the Jakobshavn drainage basin, at surface elevations lower than about $1400 \mathrm{~m}$, there is considerable surface melting in summer,

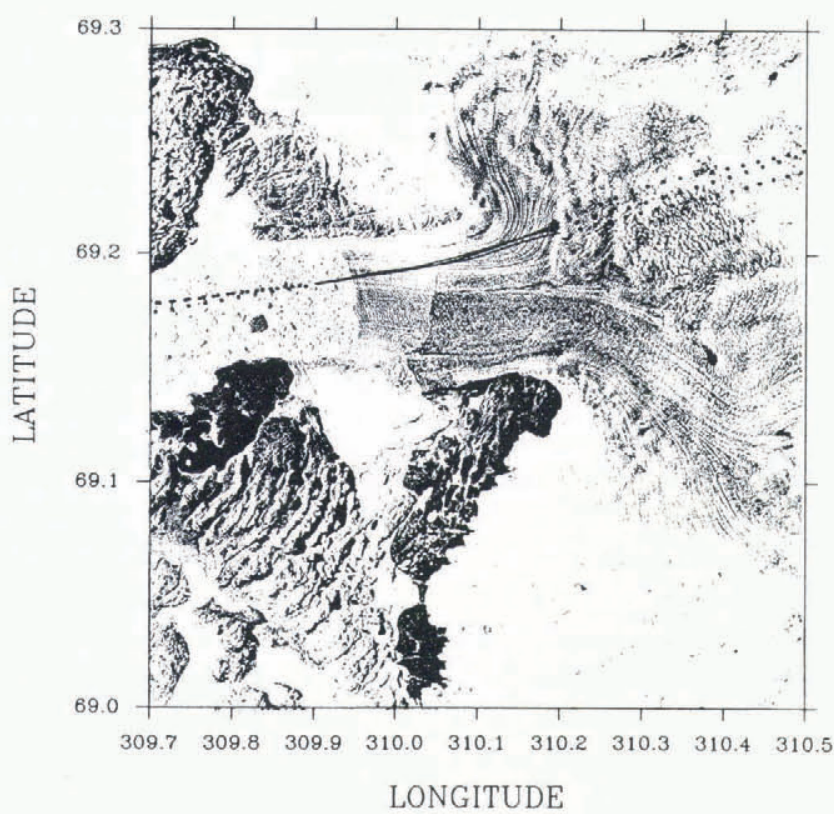

Fig. 2. Pholo map of Jakobshavns Isbra, showing routes of aircraft laser-altimetry flights. (Compiled by $H$. Brecher, The Ohio Slate University.) with fast-flowing melt streams cutting into the ice, and large lakes of meltwater forming in depressions (Thomsen and others, 1989). The intense melting thins the ice and lowers the surface elevation to a minimum at the end of the melt season. In winter, heavy snow accumulation, as well as advection of the steeply sloping ice, raises the surface elevation to a maximum at the beginning of the melt season. Because Jakobshavns Isbræ is so active, we expected this seasonal thickening and thinning to be quite large, providing an opportunity to test the ability of the airborne altimetry system to detect changes in surface elevation.

Figure 3 shows an elevation profile over the lower reaches of Jakobshavns Isbræ, derived from airborne data collected in 1991, with elevation changes between 1991 and 1992, and between 1991 and 1993, also plotted. The most obvious change between 1991 and 1992 is the thickening in Figure 3B by several tens of meters between longitudes $309.95^{\circ}$ and $310.0^{\circ} \mathrm{E}$. This represents an advance of the glacier front by about $2 \mathrm{~km}$, which does not fully reflect the glacier speed since there was undoubtedly significant calving of icebergs in the interim. By July 1993 the glacier front had retreated slightly behind its 1991 calving position, as indicated by the strong thinning inland from longitude $310.0^{\circ} \mathrm{E}$ in Figure 3C. Thickness change near the ice front is obscured by movement of ice pinnacles along the profile. Upstream, between longitudes $310.1^{\circ}$ and $310.2^{\circ} \mathrm{E}$, the glacier thickened by several meters between September 1991 and April 1992. We expect this to be balanced to some extent by subsequent summer melting, but a very cold
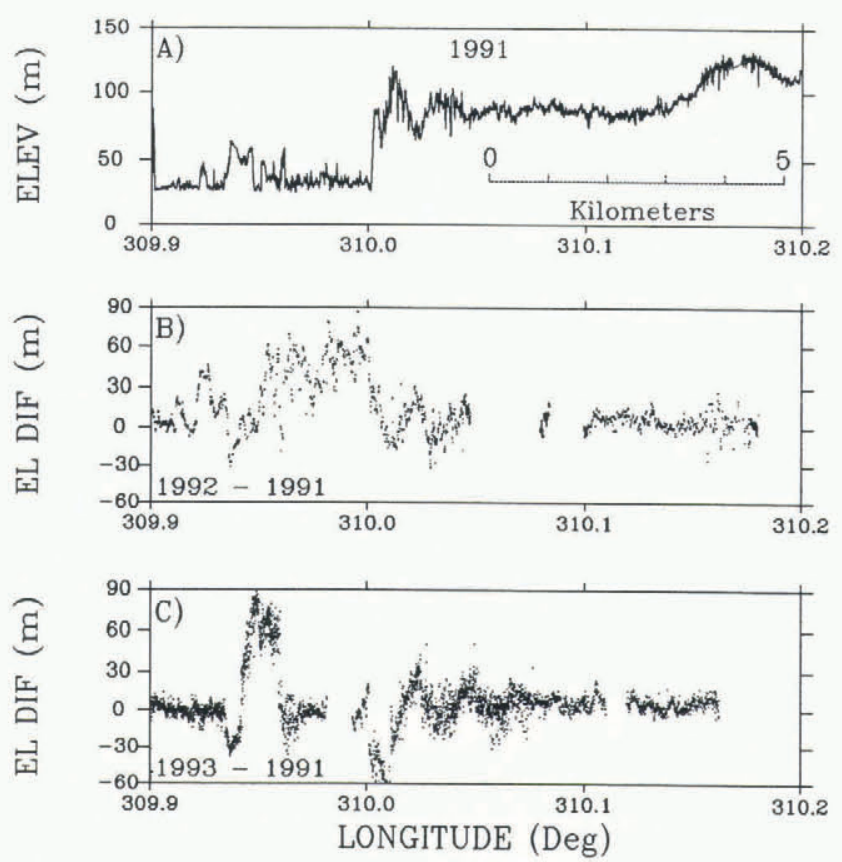

Fig. 3. A. Surface profile of Jakobshavns Isbra derived from the 1991 laser flights, with plots of elevation differences B. from 1991 to 1992, and C. from 1991 to 1993, at locations where laler flights were coincident with 1991 measurements. The calving front of the glacier was at longitude $310^{\circ} \mathrm{E}$ in 1991, al $309.95^{\circ} \mathrm{E}$ in 1992 and at 310.01 $\mathrm{E}$ in 1993. Pinnacles seaward of the ice front are icebergs. 
summer in 1992, and the overall thickening (of perhaps $3 \mathrm{~m}$ ), still shows in the comparison of data from 1991 and 1993, despite a very warm 1993 summer with record melting in many parts of the ablation zone.

Figure 4 shows elevation profiles and elevation changes farther upstream, where the glacier surface is free of crevasses and pinnacles. Here, between 1991 and 1992, the ice thickened by almost $2 \mathrm{~m}$, but the thickening west of $310.9^{\circ} \mathrm{E}$ longitude was cyclic along the profile. This was caused by surface undulations moving forward with the glacier. These undulations were superimposed on the larger-scale topography. They had a wavelength of about $600 \mathrm{~m}$ and amplitude of $23 \mathrm{~m}$, and in the $7 \mathrm{month}$ interim between observations they had shifted to be almost exactly out of phase with the earlier observations. Comparison of the two sets of data yielded a sinusoidal curve with an amplitude of about $5 \mathrm{~m}$. East of $310.9^{\circ} \mathrm{E}$ longitude, surface undulations become more erratic, and the comparisons are less regular.

Figure 4 suggests that the thickening between 1991 and 1992 was sustained through to the summer of 1993 , by which time it averaged about $2 \mathrm{~m}$. This cannot be interpreted as representing a trend; inter-annual variability in the ablation region is very large, and could cause short-term raising or lowering of the surface by several meters (Braithwaite, in press). The very cold summer of
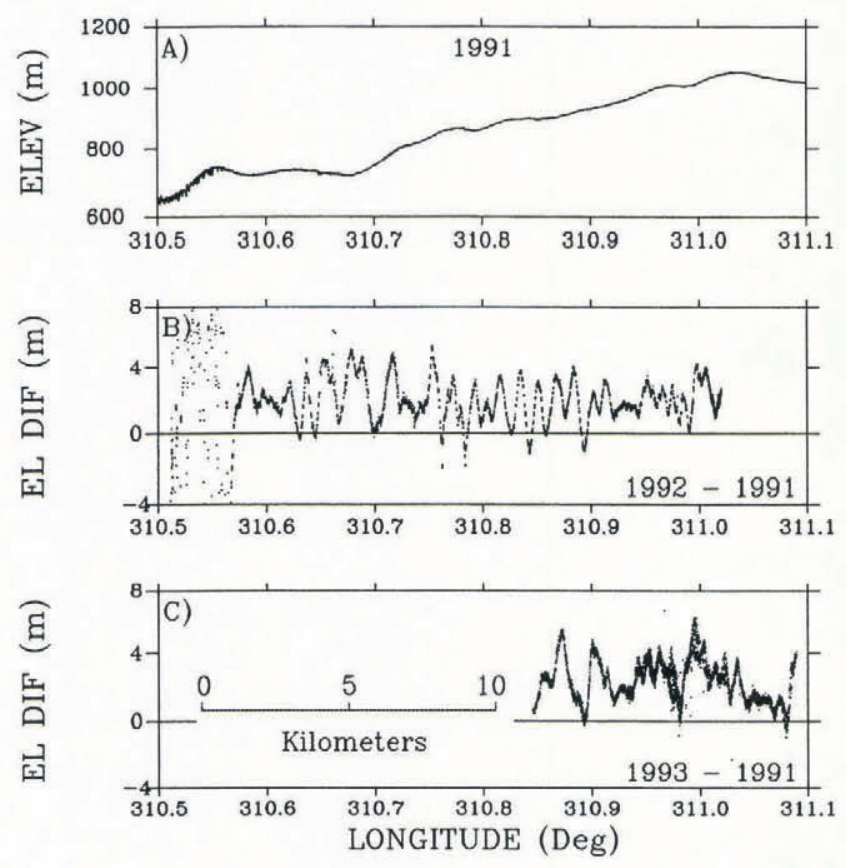

Fig. 4. The 1991 surface profile of Jakobshauns Isbre inland of that shown in Figure 3. Most of this region is crevasse-free, and the elevation-difference plots show a thickening trend of about $2 \mathrm{~m}$, with a strong cyclic variation in thickening rate. Most of the thickening occurred between September 1991 and April 1992.
1992 will certainly have affected ablation rates, and the full effects of 1993 summer melting are not reflected in our data, which were acquired on 9 July with several weeks of melting still to come.

\section{CONCLUSIONS}

NASA has developed an airborne capability to measure ice-surface elevations to an accuracy of about $10 \mathrm{~cm}$ over flight lines of several hundred kilometers. The instruments needed to achieve this are a scanning laser altimeter and GPS receivers linked to various antennas on the aircraft. Other instruments that are routinely included on over-ice missions are nadir-looking laser and radar altimeters, and a low-frequency ice-penetrating radar.

The results presented here reveal seasonal and interannual thickening, by several meters, in the lower reaches of Jakobshavns Isbrx, up to an altitude of $1000 \mathrm{~m}$ or more. Such inter-annual changes in surface elevation are to be expected in areas of strong ablation. We repeated the flights over Jakobshavns Isbre in June 1994, and plan periodic additional flights in the future. These will allow us to assess more rigorously the effects of inter-annual variations in ablation and snow accumulation and, if they are sustained for a long enough period, to determine longterm trends in ice thickness.

\section{ACKNOWLEDGEMENTS}

We thank all who helped to obtain, and to process, the aircraft-altimetry measurements; they are too numerous to identify, but they did most of the work. Funding support was provided by the NASA Polar Research Program.

\section{REFERENGES}

Braithwaite, R.J. In press. Thoughts on monitoring the effects of climate change on the surface elevation of the Greenland ice sheet. Global and Planetary Change.

Krabill, W. B. and C. F. Martin. 1987. Aircraft positioning using Global Positioning System carrier phase data. f. Inst. Navig., 34 1), 1-21.

Krabill, W. B. and R. N. Swift. 1985. Airborne lidar experiments at the Savannah River plant. NASA Tech. Memo. 4007

Krabill, W.B., R.H. Thomas, C.F. Martin, R.N. Swift and E. B. Frederick. In press. Accuracy of airborne laser altimetry over the Greenland ice sheet. Int. F. Remole Sensing.

Thomsen, H. H., O. B. Olesen, R.J. Braithwaite and A. Weidick. 1989. Greenland ice-margin programme, a pilot study at Pakitsoq, northeast of Jakobshavn, central West Greenland. Gronlands Geologiske Undersogelse, Rapport, 145, 50-53.

Wright, C. W. 1992. Applications of new GPS aircraft control/display system to topographic mapping of the Greenland ice cap. In Proceedings SPIE Conference, Orlando, FL, April 22-23. Washington, DC, Bellingham Press, 27.

Zwally, H.J., A. C. Brenner, J. A. Major, R. A. Bindschadler and J. G. Marsh. 1989. Growth of the Greenland ice sheet: measurement. Science, 246 (4937), 1587-1589. 